\title{
Predation effects on early post-settlement survivorship of coral-reef fishes*
}

\author{
Mark H. Carr**, Mark A. Hixon*** \\ Department of Zoology, Oregon State University, Corvallis, Oregon 97331-2914, USA
}

\begin{abstract}
Little is known of the sources of mortality that affect local population dynamics of coralreef fishes. To examine the role of predation, resident piscivorous fishes [moray eels (Muraenidae), large squirrelfishes (Holocentridae), groupers (Serranidae), and snappers (Lutjanidae)] were removed from 3 of 6 isolated patch reefs of living coral near Lee Stocking Island, Bahamas, in 1992. All 6 reefs were then seeded with natural densities of newly settled recruits of 3 species: Chromis cyanea (blue chromis, Pomacentridae), Halichoeres pictus (rainbow wrasse, Labridae), and Thalassoma bifasciatum (bluehead wrasse, Labridae). Controls showed that any secondary effects of transplanting new recruits were negligible. Over the next month, survivorship of $C$. cyanea (mean: $41.3 \%$ ) and $\mathrm{H}$. pictus $(80.8 \%$ ) on the predator-absent reefs was significantly greater than on the predator-present (control) reefs $(9.4 \%$ for $C$. cyanea and $43.2 \%$ for $H$. pictus). No statistical difference was evident for $T$ bitasciatum ( 48.5 vs $37.8 \%$ survival), perhaps because juveniles of this species are cleaner fish and/or because they were less conspicuous to predators than the other species. Although the size distributions of the wrasses did not differ between treatments, the size distribution of C. cyanea shifted significantly. At the end of the experiment, surviving $C$. cyanea were slightly larger on the predator-present reefs (mode = $4.0 \mathrm{~cm}$ total length, TL) than on the predator-absent reefs (mode $=3.5 \mathrm{~cm} \mathrm{TL}$ ), despite no significant difference at the start of the experiment (mode for both treatments $=3.0 \mathrm{~cm} \mathrm{TL}$ ). We interpret this size shift as predators differentially consuming smaller recruits and/or surviving recruits growing faster after densities were reduced by predators. Preliminary remote video monitoring of the activity of transient puscivores [mostly jacks (Carangidae)] over the experimental reefs suggested that such predators may regularly visit isolated reefs in search of prey. If so, transient predators may have accounted for the surprisingly low first-month survivorship (about 40 to $80 \%$ ) of new recruits on reefs where resident predators were removed. In any case, we conclude that resident predators can substantially alter the local density and size structure of reef fishes shortly after they settle from the plankton. Because piscivores differentially affected the survivorship of different species, predation may also influence the structure of reef-fish communities by altering the relative abundances of prey species established at the time of settlement.
\end{abstract}

KEY WORDS: Coral-reef fishes $\cdot$ Predation $\cdot$ Recruitment $\cdot$ Size distribution $\cdot$ Survivorship

\section{INTRODUCTION}

Local population dynamics of most marine organisms are driven by recruitment, mortality, immigration, and emigration, where 'recruitment' is the process of settlement and subsequent establishment

\footnotetext{
- Sequence of authorship determined by a coin toss

- Present address: Marine Science Institute, University of California, Santa Barbara, CA 93106, USA

-..Addressee for correspondence

E-mail: hixonm@bcc.orst. edu

of dispersive larvae or spores. Both recruitment and mortality have been closely examined in studies of sessile marine invertebrates with planktonic larvae (e.g. Underwood et al. 1983, Connell 1985, Gaines \& Roughgarden 1985, Underwood \& Fairweather 1989, Raimondi 1990, Menge 1991), as well as macroalgae with dispersive spores (e.g. Reed et al. 1988, Reed 1990, Santelices 1990). However, for coral-reef fishes, which typically have highly dispersive larvae (Leis 1991), much more is known about the process of recruitment than patterns of post-settlement mortality and between-reef movements (reviews by Doherty \& 
Williams 1988, Doherty 1991, Hixon 1991, Jones 1991. Sale 1991). Clearly, without knowledge of the sources and patterns of post-settlement mortality, our understanding of the population dynamics of reef fishes is incomplete.

Predation appears to be the major cause of mortality of reef-associated fishes, especially of new recruits (Shulman \& Ogden 1987, Hixon 1991, Caley 1993. Hixon \& Beets 1993). A variety of predators are abundant on most reefs (review by Hixon 1991); and indeed, some reef fishes become piscivorous soon after settling (Sweatman 1993). Local survivorship, defined here as persistence on a particular reef (thus including both mortality and emigration), is notoriously low shortly after settlement (reviews by Sale \& Farrell 1988, Hixon 1991)

Despite such circumstantial evidence, there have been only 2 well-controlled experimental manipulations of predators on coral reefs designed to examine effects on the early survival of new recruits. Doherty \& Sale (1985) monitored recruitment to plots that were caged, partially caged (cage control), and uncaged (open control) at One Tree Island, Great Barrier Reef. The average outcome of all trials was that there were always more new recruits in the full cages than the partial cages or open plots, especially for a group of solitary, sedentary species. However, high variances and caging artifacts precluded clear inferences of predator effects. Also at One Tree Island, Caley (1993) removed predatory fishes from 10 of 20 artificial reefs. The study reefs were separated by only $10 \mathrm{~m}$ of open sand, so that predators recolonized the reefs between censuses. Nonetheless, recruits of 2 of 7 species analyzed and larger residents of 3 of 9 species analyzed became significantly more abundant on the predatorabsent reefs compared to predator-present reefs.

Other attempts to manipulate predatory reef fishes have been largely unsuccessful due to insufficient isolation of experimental reefs, which allowed immigration of new predators to swamp removals (review by Hixon 1991). Such experiments face other difficulties in that predators vary in their foraging ranges. As reviewed by Hixon (1991), some piscivores live with their prey on a single reef [full-time residents, such as some large squirrelfishes (Holocentridae) and groupers (Serranidae)], some are reef associated but occasionally move between reefs [part-time residents, such as some moray eels (Muraenidae) and snappers (Lutjanidae)j, and others forage among reefs [transients, such as some jacks (Carangidae) and barracuda (Sphyraenidae)]. Less direct experiments have demonstrated the importance of structural refuge from predators in enhancing survival of new recruits (Shulman 1985. Hixon \& Beets 1989, 1993). Knowledge of the effects of immigration and emigration of new recruits on local population dynamics are even more limited (Robertson 1988, Forrester 1990), although these processes appear to be negligible for site-attached species on highly isolated reefs (Forrester 1990).

Our goal was to determine experimentally the effects, if any, of resident piscivorous fishes on the early survivorship and size distributions of new recruits of several species of coral-reef fishes. We accomplished this objective by controlled removals of predatory fishes from very isolated patch reefs. We also monitored the activity of transient piscivores at these reefs to gain some insight on their potential effects. Our results show that resident predators accounted for significant mortality of 2 species within 1 mo of settlement and that there were measurable effects of predation on the size distribution of new recruits of 1 species. Because predator-induced mortality differed among species of recruits, predation may influence community structure by altering the relative abundances of species established at the time of settlement. Our data also indicate that schools of transient predatory jacks regularly visited the experimental reefs and, consequently, may also affect postsettlement survivorship.

\section{METHODS}

Study site. Our study site was near the Caribbean Marine Research Center at Lee Stocking Island, $7 \mathrm{~km}$ north of Exuma Island, Bahamas (Fig. 1). This and other islands of the Exuma archipelago run approximately north to south, acting as a boundary between the deep oceanic Exuma Sound to the east and the very shallow Great Bahama Bank to the west. Coral patch reefs, dominated by Montastrea annularis and Porites asteroides, are scattered at depths of 1 to $30 \mathrm{~m}$ along the eastern coasts of the islands and are relatively uncommon west of the islands in the 2 to $4 \mathrm{~m}$ deep waters of the sand-dominated bank

Fish censuses. Patch reefs were censused completely by pairs of SCUBA divers, as detailed by Hixon \& Beets $(1989,1993)$. Total lengths (TL) of all individuals of each species were estimated by observation of fish as they swam past ruled, underwater slates. New recruits (identified by their small size and partial pigmentation) were estimated to the nearest $0.5 \mathrm{~cm} \mathrm{TL}$, fish from 5 to $30 \mathrm{~cm}$ to the nearest centimeter, and larger fish to the nearest $5 \mathrm{~cm}$. Both fish counts and size estimates were highly concordant between observers (Hixon \& Carr unpubl.), so that any sampling bias was consistent through time and across experimental treatments.

The density of fish was calculated by dividing counts by the estimated surface area of a reef. Because the reefs are roughly cylindrical in shape, reef area was 
Fig. 1 Study site near the Caribbean Marine Research Center (CMRC), Lee Stocking Island, Bahamas. (•) Locations of 6 translocated patch reefs used in the predator-removal experiment; (o) 2 translocated monitoring reefs not included in the experiment; (口) sets of patch reefs used in the transplant-control experiment (northeast of Norman's Pond Cay: unmanipulated and handling treatments; southwest: transplant treatment)

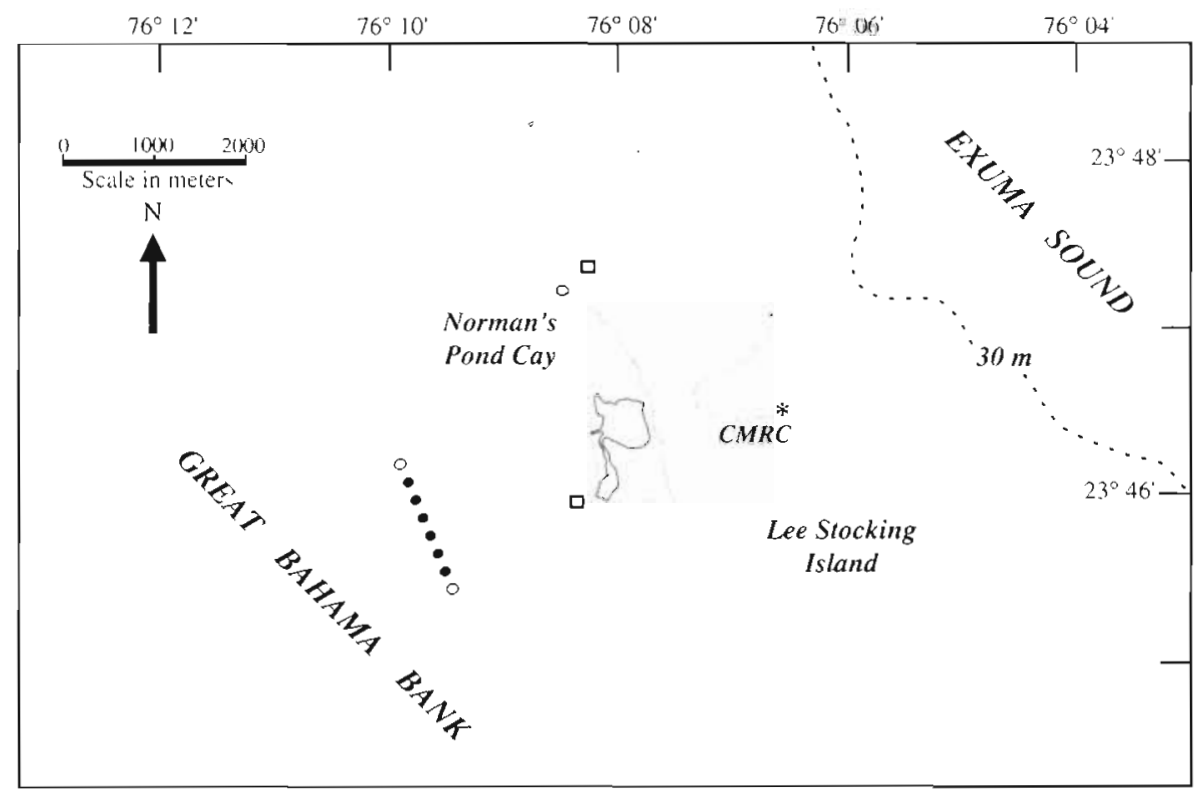

estimated as the surface area of the minimum oval cylinder that could contain a reef (i.e. multiplying the area of an oval calculated from the orthogonal diameters of a reef, times the height, times the circumference of the reef).

Experimental design. We conducted our experiments during the peak recruitment period in the Exumas, June to August. During a preliminary study in 1991, we attempted predator-removal experiments on the 10 most isolated natural patch reefs in our study area, each located 10 to $200 \mathrm{~m}$ from its nearest neighbor $(\bar{x}=19.5 \mathrm{~m}, \mathrm{SD}=8.6 \mathrm{~m}, \mathrm{n}=10)$. However, reefs from which predators had been removed were swamped by immigration on all but the 2 most isolated of these reefs, so this experiment was terminated. On the single pair of sufficiently isolated reefs, new recruits of beaugregory damselfish Stegastes leucostictus accumulated more rapidly on the predatorabsent reef than the predator-present reef (Carr \& Hixon unpubl.). These results indicated that, although predation effects were detectable, subsequent experiments would require reefs that were sufficiently isolated to inhibit immigration from swamping predator removals.

For our later experiments, we transplanted entire natural patch reefs to a large sand flat west of Norman's Pond Cay (Fig. 1). In August 1991, we used the RV 'Exuma Hunter' to translocate large $(\geq 0.5 \mathrm{~m}$ diameter) coral heads without removing them from the water. This vessel is a motorized aluminum catamaran with a central platform that lowers about $3 \mathrm{~m}$ into the water. At $3 \mathrm{~m}$ depths, groups of divers gently loaded individual coral heads onto this platform, which was subsequently raised to just below the surface for trans- porting the corals underwater. At each desired location, the platform was lowered and 6 to 8 coral heads were deployed, recreating patch reefs 2 to $3 \mathrm{~m}$ in diameter. We arranged 6 such patch reefs in a row with $200 \mathrm{~m}$ between adjacent reefs (Fig. 1). This unprecedented transplanting of entire patch reefs ensured equal and sufficient isolation of reefs, which provided independent experimental replicates from which predators could be effectively removed. As of late 1994, the transplanted corals had survived with little detectable polyp mortality for over $3.5 \mathrm{yr}$. (In early April 1992, 2 additional patch reefs, which were not used in the experiment, were transplanted -1 at each end of the original row.)

Censuses in May 1992, before the summer recruitment season, revealed that fishes had colonized the translocated reefs to a mean density of 6 fish $\mathrm{m}^{-2}$ (population $\mathrm{SD}=4.5$ ) and an average of 9 species $(\mathrm{SD}=$ 2.4), compared to 6 unmoved reference reefs with a mean density of 10 fish $\mathrm{m}^{-2}(\mathrm{SD}=4.0)$ and an average of 13 species $(S D=2.8)$. Thus, just before our experiments, the transplanted reefs supported about twothirds the density and species richness of fishes of similar unmoved reefs.

In early July 1992, all resident predators were removed from alternate reefs of the central 6 transplants, resulting in 3 predator-absent reefs alternating with 3 predator-present (control) reefs. Table 1 gives the species and abundances of these predators. (Predators were also removed from the remaining 2 end reefs, which subsequently served as sites for monitoring natural recruitment rates concurrent with, but independent of, the experiment.) Throughout the month-long experiment, we speared any new predators that immi- 
Table 1. Abundances of resident piscivorous fishes on 3 predator-present (control) reefs and 3 predator-absent (predators removed) reefs, both before (baseline period) and during the predator-removal experiment. Baseline columns give the mean (and population SD, $\mathrm{n}=3$ ) of the mean number of fish on each reef from 26 censuses between 27 May and 12 July 1992 ; experimental columns give the same statistics from 23 censuses between 20 July and 16 August 1992. Non-zero means on the predator-absent reefs during the experimental period represent immigrants that were removed immediately after being censused. Predators identified from gut contents (Randall 1967 and pers. obs.); note that the squirrelfish is not normally piscivorous, but was manipulated because it is a large generalized camivore

\begin{tabular}{|c|c|c|c|c|}
\hline \multirow[t]{2}{*}{ Predator family/species } & \multicolumn{2}{|c|}{ Predator-present reefs } & \multicolumn{2}{|c|}{ Predator-absent reefs } \\
\hline & Baseline period & Experimental period & Baseline period & Experimental period \\
\hline \multicolumn{5}{|l|}{ Muraenidae (moray eels) } \\
\hline Gymnothorax moringa & $0.17(0.24)$ & $0.01(0.02)$ & $0.33(0.37)$ & 0 \\
\hline Gymnothorax vicinus & $0.33(0.47)$ & $0.23(0.33)$ & 0 & 0 \\
\hline \multicolumn{5}{|l|}{ Holocentridae (squirrelfishes) } \\
\hline Holocentrus ascensionis & $0.01(0.02)$ & $0.32(0.45)$ & $0.01(0.02)$ & $0.06(0.04)$ \\
\hline \multicolumn{5}{|l|}{ Serranidae (groupers) } \\
\hline Epinephelus guttatus & $0.32(0.45)$ & $0.33(0.47)$ & 0 & 0 \\
\hline Epinephelus striatus & $4.99(1.38)$ & $3.44(0.59)$ & $4.37(1.55)$ & $0.06(0.08)$ \\
\hline \multicolumn{5}{|l|}{ Lutjanidae (snappers) } \\
\hline Lutjanus analis & $0.10(0.15)$ & $0.01(0.02)$ & $0.01(0.02)$ & 0 \\
\hline Lutjanus apodus & 0 & $0.01(0.02)$ & 0 & 0 \\
\hline Lutjanus synagris & $0.45(0.31)$ & $0.58(0.42)$ & $0.23(0.23)$ & $0.03(0.04)$ \\
\hline Total predators & $6.37(0.82)$ & $4.93(1.00)$ & $4.95(2.12)$ & $0.15(0.08)$ \\
\hline
\end{tabular}

grated to the predator-absent reefs in the 24 to $48 \mathrm{~h}$ between censuses.

An advantage of the transplanted reefs was that they were located in a settlement shadow to the west of Norman's Pond Cay (Fig. 1). This situation enabled us to control recruit densities by translocating new settlers from natural patch reefs on the east side to our experimental reefs on the west side without the confounding effects of natural settlement (see 'Results'). We transplanted 3 species: Chromis cyanea (blue chromis, Pomacentridae), Halichoeres pictus (rainbow wrasse, Labridae), and Thalassoma bifasciatum (bluehead wrasse, Labridae). As new recruits, all 3 species are gregarious, planktivorous, and highly site attached (author's pers. obs.). New recruits (averaging $2 \mathrm{~cm}$ TL for $H$. pictus and $T$. bifasciatum and $3 \mathrm{~cm} \mathrm{TL}$ for $C$ cyanea) were captured by divers with nets at 2 to $4 \mathrm{~m}$

Table 2. Companson of mean (and population SD) reef fish recruit densities (no. $\mathrm{m}^{-2}$ ) on experimentally translocated coral patch reefs vs unmoved patch reefs at the start of the predator-removal experiment

\begin{tabular}{|lcccccc|}
\hline Species & $\begin{array}{c}\text { Translocated } \\
\text { reefs }\end{array}$ & \multicolumn{2}{c|}{$\begin{array}{c}\text { Unmoved } \\
\text { reefs }\end{array}$} \\
& Mean (SD) & $\mathrm{n}$ & Mean (SD) & $\mathrm{n}$ \\
\hline Chromis cyanea & 3.50 & $(0.44)$ & 5 & 2.48 & $(0.88)$ & 15 \\
Halichoeres pictus & 5.30 & $(0.59)$ & 6 & 3.95 & $(3.82)$ & 14 \\
Thalassoma bifasciatum & 6.40 & $(1.43)$ & 6 & 5.10 & $(2.86)$ & 10 \\
Reef area $\left(\mathrm{m}^{2}\right)$ & 4.10 & $(0.54)$ & 6 & 5.90 & $(3.50)$ & 32 \\
\hline
\end{tabular}

depth on the east side of Norman's Pond Cay. These fish were transferred to buckets, measured, and immediately transported to the 6 experimental reefs on the west side. By 19 July, the day before we began the experiment, each reef supported 15 to $40 \mathrm{C}$. Cyanea $(\bar{x}=24, \mathrm{SD}=9.4), 20$ to $25 \mathrm{H}$. pictus $(\bar{x}=23, \mathrm{SD}=2.1)$, and 21 to $35 T$. bifasciatum $(\bar{x}=29, \mathrm{SD}=6.0)$.

To account for any injury and subsequent mortality immediately caused by the transplanting procedure, we waited 24 h after the recruits were transplanted for our first 'post-manipulation' census (i.e. 'Day $0^{\prime}$ ). This conservative approach allowed any fish injured in transit to disappear before we attempted to measure any predation effects. On Day 0 following the $24 \mathrm{~h}$ adjustment period, the densities of transplanted recruits were near the averages observed on unmanipulated natural patch reefs on the east side of Norman's Pond Cay (Table 2). From Day 0 onward, each reef was censused almost daily for $27 \mathrm{~d}$

Transplant control. The 3 species we transplanted are highly reef-associated (de Boer 1978, Victor 1986, Hunt von Herbing \& Hunte 1991, Booth \& Beretta 1994, author's pers. obs.). However, if transplanting recently settled recruits from their home patch reefs to the experimental reefs substantially increased their rate of emigration and/or vulnerability to predators, differences in survivorship between reefs with and without predators might be artificially exacerbated. In addition to delaying the start of the main experiment until $1 \mathrm{~d}$ after transplanting recruits, we conducted a separate transplant-control experiment to test for these 
unwanted effects. We used only Halichoeres pictus in this experiment because of the relatively high availability of new recruits of this species in 1992. However, in 1994, we conducted the same transplant-control experiment using Chromis cyanea (Hixon \& Carr unpubl.).

Concurrent with our main experiment in 1992, we censused new recruits on 16 natural patch reefs east of Norman's Pond Cay (Fig. 1), then captured all recruits from 10 of these reefs. Fish from 5 reefs were transplanted to 5 similar patch reefs on the west side of Norman's Pond near our experimental reefs ('transplant' treatment). Recruits from the other 5 reefs were returned to the reefs from which they were captured after the same amount of handling ('handling' treatment). The 6 remaining reefs served as unmanipulated controls. We then censused the reefs every other day for 1 mo. The isolation, surface area, and predator populations of the 16 experimental reefs were also measured for comparison.

Data analysis. Unlike any of the other transplanted cohorts in both the predator-removal experiment and the transplant-control experiment, an entire cohort of new recruits disappeared from one reef in each experiment within $24 \mathrm{~h}$ after being transplanted (i.e. before the beginning of each experiment). Therefore, these 2 reefs were excluded from analysis for the affected species (see 'Discussion').

For both the predator-removal and transplant-control experiments, we compared treatments in 2 ways. First, to compare loss rates between treatments, slopes of linearized survivorship curves were calculated for each replicate cohort based on $\log (x+1)$-transformed percentages including all sampling dates. When necessary to achieve homogeneity of variances, the absolute value of the slope was log transformed and used in a 1-way, fixed factor ANOVA, with associated a priori contrasts. Second, to compare final survivorship between treatments, a 1-way, fixed-factor ANOVA was used to compare the transformed $[\arcsin (\sqrt{X})]$ proportions of recruits remaining on replicate reefs on the last day of each experiment. All analyses were run using the SAS microcomputer package (SAS Institute Inc. 1988). In both sets of analyses, use of ANOVA was justified on the basis that Bartlett's tests showed the transformed data to be either homogeneous $(p>0.05)$ or only marginally heterogeneous (0.05 > p $\geq 0.035)$.

Video observations. Although we were able to manipulate resident predators, we could not control transient predators (jacks and barracuda). These fishes visited all the reefs, and it appeared that the presence of divers attracted these transients. To monitor the activity and potential impact of these piscivores at the experimental reefs in the absence of divers, we deployed an underwater hi-8 $\mathrm{mm}$ video camera pro- grammed to run for $24 \mathrm{~min}$ at 06:15 (dawn), 08:30, 11:00, 15:30, and 19:45 h (dusk) over a $24 \mathrm{~h}$ period (which completely filled a $2 \mathrm{~h}$ videotape). The camera was positioned about $3 \mathrm{~m}$ from a reef, the minimum distance from which the entire reef could be viewed. Reviewing the videotape in the laboratory allowed us to estimate both the number of 'predator-minutes' each species spent in view over the reef and the number of any 'predatory strikes' the fish made toward the reef during each observation period. Note that total predator-minutes could potentially exceed total observation time due to multiple predators simultaneously swimming over a reef. During the predator-removal experiment, we video sampled all 6 reefs an average of $5.1 \mathrm{~h}$ each, totaling $30.8 \mathrm{~h}$ of observation.

\section{RESULTS}

\section{Transplant controIs}

The transplant-control experiment examined whether moving new recruits of Halichoeres pictus to unfamiliar reefs artificially affected their survivorship on those reefs. Reduced survival of handled and/or transplanted recruits (relative to unmanipulated controls) would indicate that moving fish to experimental reefs could artificially increase their susceptibility to predation, thereby unrealistically inflating any predation effect detected by the main experiment. Initial cohort size, reef surface area, degree of isolation from nearby reefs, and number of predators on the 16 reefs used in the transplant-control experiment did not differ significantly among the 3 treatments (Table 3). Note that mean reef area was substantially greater in the handling treatment, but only because of 1 large reef (the mean $\pm \mathrm{SE}$ for this treatment drops to $8.8 \pm 2.1 \mathrm{~m}^{2}$ if this reef is excluded). Therefore, any differences between groups of reefs could be safely attributed to the 3 experimental treatments.

Among the 3 treatments, the rates of loss of recruits and the final proportion of fish remaining after 1 mo were very similar (Fig. 2). Mean ( \pm SE) loss rates (i.e. slopes of logged survivorship curves) were -0.025 $( \pm 0.004)$ for the control treatment, $-0.025( \pm 0.004)$ for the handling treatment, and $-0.021( \pm 0.003)$ for the transplant treatment ( $\mathrm{n}=6,5$, and 4 reefs, respectively). Mean ( \pm SE) proportion of recruits remaining on Day 29 was $0.27( \pm 0.07)$ for the control treatment, $0.25( \pm 0.11)$ for the handling treatment, and $0.31( \pm 0.11)$ for the transplant treatment. Thus, we did not detect significant handling effects (unmanipulated vs handling treatments) or effects of reef familiarity (handling vs transplant treatments) on the survivorship of transplanted new recruits (Fig. 2; Tables 4 \& 5). Repeating 
Table 3. Halichoeres pictus. Transplant-control experiment. (A) Mean (SE) starting cohort size (no. of ind.), reef surface area, isolation from nearest neighboring reef, and number of predators on reefs among the 3 treatments used to assess effects of transplanting on loss rates of transplanted cohorts. (B) One-way, fixed-factor ANOVA results for $\log (x+1)$-transformed variates

\begin{tabular}{|c|c|c|c|c|c|}
\hline t & \multicolumn{2}{|c|}{ Unmanipulated } & $\begin{array}{c}\text { Treatmen } \\
\text { Handled } \\
5\end{array}$ & Trar & $\begin{array}{l}\text { planted } \\
4\end{array}$ \\
\hline Initial cohort size & 26.3 & (3.7) & $34.4(6.1)$ & & $(3.1)$ \\
\hline Reef area $\left(\mathrm{m}^{2}\right)$ & 7.2 & (2.1) & $17.5(7.6)$ & & $(2.1)$ \\
\hline Isolation (m) & 9.9 & (3.3) & $7.6(1.9)$ & & $(2.1)$ \\
\hline $\begin{array}{l}\text { Predator } \\
\text { abundance }\end{array}$ & 1.9 & $(0.5)$ & $1.8(0.5)$ & & $(0.5)$ \\
\hline (B) & & ANC & OVA resu & lts & \\
\hline $\begin{array}{l}\text { Dependent } \\
\text { variable }\end{array}$ & df & $\begin{array}{l}\text { Type III } \\
\text { SS }\end{array}$ & MS & $F$ & $\mathrm{p}$ \\
\hline Initial cohort size & 2 & 0.21 & 0.11 & 0.75 & 0.49 \\
\hline Reef area $\left(\mathrm{m}^{2}\right)$ & 2 & 2.06 & 1.03 & 2.12 & 0.16 \\
\hline Isolation (m) & 2 & 1.10 & 0.55 & 2.09 & 0.16 \\
\hline $\begin{array}{l}\text { Predator } \\
\text { abundance }\end{array}$ & 2 & 0.17 & 0.09 & 0.36 & 0.70 \\
\hline
\end{tabular}

the transplant-control experiment for C. cyanea in 1994 gave the same results (Hixon \& Carr unpubl.).

\section{Manipulations of resident predators}

Removal of predators from the highly isolated, translocated patch reefs was successful. On the predatorabsent reefs, there was an average of only 0.15 (SD = 0.08 ) predators per reef per census throughout the experiment, which represented 8 immigrants (never more than 2 on any reef at a time) that were removed within $1 \mathrm{~d}$ of colonization (Table 1). In contrast, there

Table 4. Halichoeres pictus. Transplant-control experiment. Effects of handling and reef familiarity on loss rates of recruit cohorts. One-way, single-factor ANOVA comparing log( $\%)$ transformed slopes of survivorship curves on control, handling, and transplant reefs (see Fig. 2)

\begin{tabular}{|lcccc|}
\hline Source of variation & df & MS & $F$ & $p$ \\
\hline Treatment & 2 & 0.101 & 0.17 & 0.847 \\
$\begin{array}{l}\text { Error } \\
\text { Corrected total }\end{array}$ & 12 & 0.596 & & \\
$\begin{array}{c}\text { Unmanipulated } \\
\text { vs handled }\end{array}$ & 14 & A priori contrasts & & \\
$\begin{array}{c}\text { Handled } \\
\text { vs transplanted }\end{array}$ & 1,12 & 0.035 & 0.06 & 0.81 \\
\hline
\end{tabular}

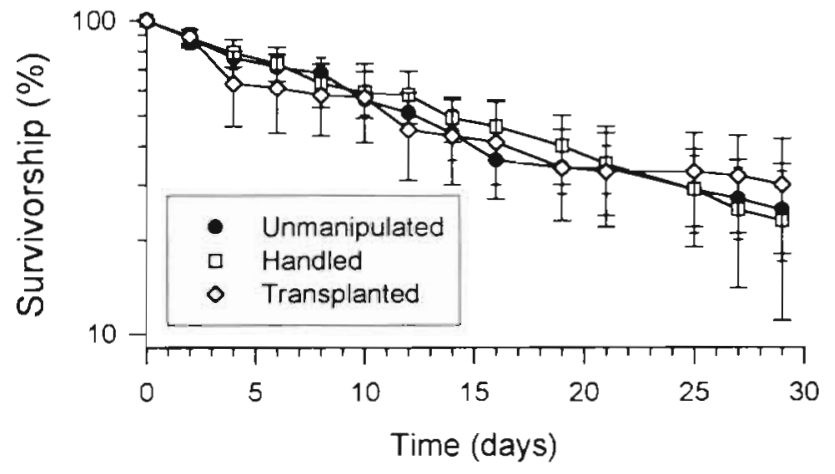

Fig. 2. Halichoeres pictus. Transplant-control experiment. Survivorship (census means $\pm \mathrm{SE}$ ) of new recruits from the east side of Norman's Pond Cay subjected to 3 treatments 'unmanipulated' control ( $\mathrm{n}=6$ reefs); 'handled', where fish were captured, transported and returned to the same reef ( $\mathrm{n}=$ 5): and 'transplanted', where fish were transplanted to reefs on the west side of Norman's Pond Cay $(n=4)$. There are no signiticant differences between treatments (see Tables $4 \& 5$ )

was an average of $4.93(\mathrm{SD}=1.00)$ predators on each predator-present (control) reef during the experiment, mostly Epinephelus striatus (Nassau grouper, Table 1).

During the experiment, natural recruitment of the 3 study species was very low on the transplanted reefs. Only 1 new Chromis cyanea and 8 Thalassoma bifasciatum (and no Halichoeres pictus) appeared on the 6 experimental reefs ( $1 T$ bifasciatum recruited to each of 5 reefs, and 3 recruited to 1 reef). On the 2 monitoring reefs, only $2 C$. cyanea appeared. Because the natural recruits were younger than the experimentally transplanted fish, they were easy to distinguish. Such low natural recruitment, especially on the 5 reefs lacking resident predators, suggests that natural settlement among the experimental reefs was sufficiently low so as to not confound patterns of survivorship of the transplanted cohorts.

The 3 species of new recruits differed markedly in their response to the predator manipulations. At the

Table 5. Halichoeres pictus. Transplant-control experiment. Effects of handling and reef familiarity on survival of recruit cohorts One-way ANOVA on arcsin $(\bar{x})$-transformed mean proportions of fish remaining on Day 28 on control, handling, and transplant reefs

\begin{tabular}{lcccc|}
\hline Source of variation & df & MS & $F$ & $p$ \\
\hline $\begin{array}{l}\text { Treatment } \\
\text { Error }\end{array}$ & 2 & 0.040 & 0.15 & 0.86 \\
$\begin{array}{l}\text { Corrected total } \\
\text { Unmanipulated }\end{array}$ & 14 & 0.267 & & \\
$\begin{array}{l}\text { v priori contrasts } \\
\text { Handled } \\
\text { vs transplanted }\end{array}$ & 1,12 & 0.017 & 0.06 & 0.81 \\
\hline
\end{tabular}


A. Chromis cyanea (blue chromis)

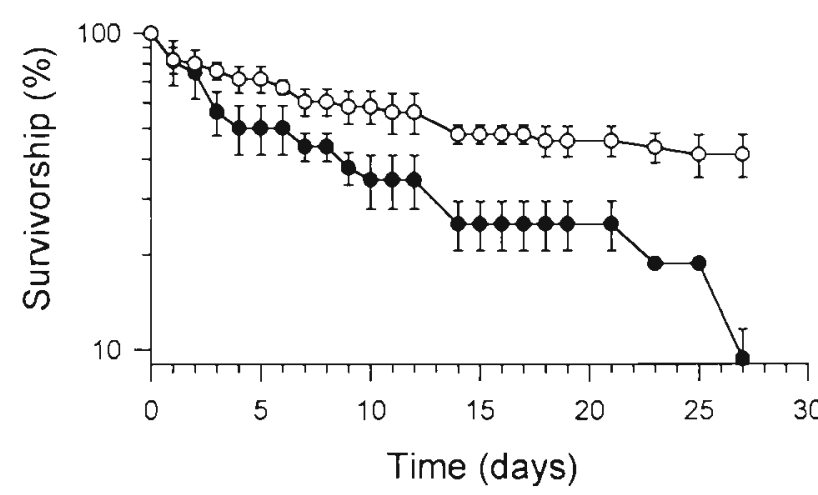

- Predators absent (removed)

- Predators present (control)

Fig. 3. Chromis cyanea, Halichoeres pictus, and Thalassoma bifasciatum. Predator-removal experiment. Survivorship of new recruits. Census means $( \pm S E)$ are for 3 replicate reefs for each predator treatment (except $C$. cyanea on control reefs, where $n=2$ ) (see Tables $6 \& 7$ )

end of the experiment, survivorship of 2 of the 3 species, Chromis cyanea and Halichoeres pictus, was significantly greater on predator-absent reefs than on adjacent control reefs (Fig. 3A, B; Table 6). However, $H$. pictus survivorship did not begin to diverge between treatments until the final week of sampling. Thus, overall survival rates of $H$. pictus were not significantly different between treatments (Fig. 3B, Table 7). Likewise, due to substantial losses on the predator-absent reefs, overall survival rates of $C$. cyanea were not significantly different between treatments (Fig. 3A, Table 7). Only about $40 \%$ of the original C. cyanea recruits

Table 6. Predator-removal experiment. Comparison of the percentage of the initial cohort remaining on the final sample date (Day 27) between predator-present (control) and predator-absent (removal) treatments. Proportions were $\arcsin (\sqrt{x})$ -

transformed for ANOVA. $n=$ number of replicate cohorts

\begin{tabular}{|c|c|c|c|c|c|}
\hline & $\mathrm{n}$ & $\begin{array}{l}\text { Control } \\
\text { Mean (SE) }\end{array}$ & n & $\begin{array}{l}\text { Memoval } \\
\text { Mean (SE) }\end{array}$ & $\mathrm{p}$ \\
\hline $\begin{array}{l}\text { Chromis } \\
\text { cyanea } \\
\text { Halichoeres }\end{array}$ & 2 & $9.4 \quad(3.1)$ & 3 & $41.3 \quad(7.8)$ & 0.04 \\
\hline $\begin{array}{l}\text { pictus } \\
\text { Thalassoma }\end{array}$ & 3 & $43.2(13.2)$ & 3 & $80.8 \quad(1.5)$ & 0.045 \\
\hline bifasciatum & 3 & $37.8(12.7)$ & 3 & $48.5(13.0)$ & 0.58 \\
\hline
\end{tabular}

\section{B. Halichoeres pictus (rainbow wrasse)}

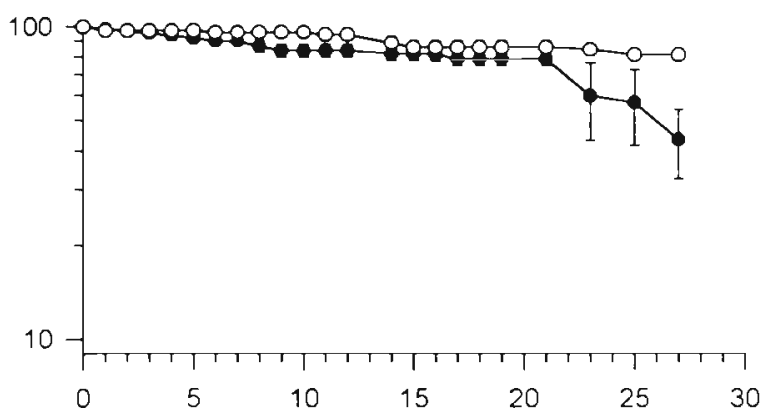

C. Thalassoma bifasciatum (bluehead wrasse)

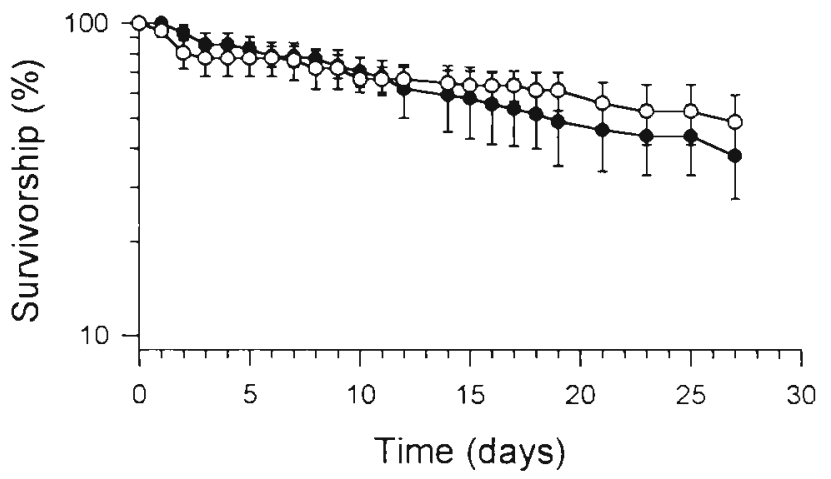

remained on the predator-absent reefs at the end of the experiment, compared to about $80 \%$ survival of $\mathrm{H}$. pictus on the same reefs (Fig $3 \mathrm{~A}, \mathrm{~B}$ ). In contrast, the predator manipulations indicated no evidence for an effect of predators on survivorship of Thalassoma bifasciatum recruits (Fig. 3C, Tables 6 \& 7).

There were also species-specific differences in the times at which predators affected survivorship. For Chromis cyanea, the greatest mortality on the predator-present reefs occurred between the second and third day of the experiment, whereas the major decline

Table 7. Predator-removal experiment. Comparison of the slopes of linearized survivorship curves between predatorpresent (control) and predator-absent (removal) treatments ANOVA based on slopes of log-transformed percentages of the initial cohort remaining on each sample date. $\mathrm{n}=$ number of replicate cohorts (see Fig. 3)

\begin{tabular}{|lccccc|}
\hline & $\begin{array}{c}\text { Control } \\
\text { n Mean (SE) }\end{array}$ & $\begin{array}{c}\text { Removal } \\
\mathrm{n} \text { Mean (SE) }\end{array}$ & $\mathrm{p}$ \\
\hline $\begin{array}{c}\text { Chromis } \\
\text { cyanea }\end{array}$ & 2 & $-2.46(0.42)$ & 3 & $-1.79(0.5)$ & 0.45 \\
$\begin{array}{c}\text { Halichoeres } \\
\text { pictus }\end{array}$ & $3-1.59(0.43)$ & $3-0.75(0.19)$ & 0.21 \\
$\begin{array}{c}\text { Thalassoma } \\
\text { bifasciatum }\end{array}$ & $3-2.31(0.93)$ & $3-1.49(0.27)$ & 0.49 \\
\hline
\end{tabular}


Start End

Predators present (control)

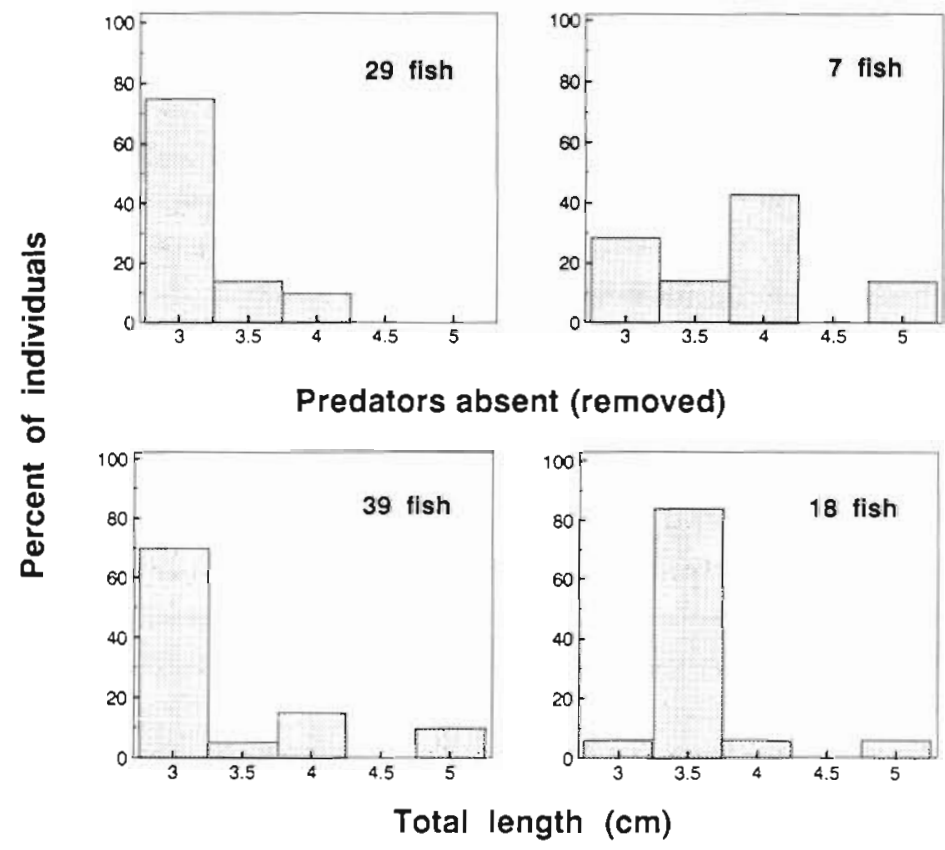

Fig. 4. Chromis cyanea. Predator-removal experiment. Size distributions of new recruits. Size distributions are for all fish on 2 replicate reefs pooled for the predator-present (control) treatment and 3 reefs for the predator-absent (removal) treatment, each at the start and near the end of the experiment

in Halichoeres pictus survival occurred during the last week between Days 21 and 27 (Fig. 3A, B).

There was evidence of size-based differential survival for Chromis cyanea, but not for the other 2 species. At the beginning of the experiment, size distributions of $C$. cyanea were not significantly different between predator-absent reefs and control reefs (Fisher's exact test between fish $\leq 3.5 \mathrm{~cm}$ vs $\geq 4.0 \mathrm{~cm} \mathrm{TL}$; $\mathrm{p}=0.21, \mathrm{n}=68$ ), with the modal size being $3.0 \mathrm{~cm} \mathrm{TL}$ in both treatments (Fig. 4). However, by the end of the experiment, survivors were significantly larger on the control reefs (mode $=4.0 \mathrm{~cm}$ TL) than on the predatorabsent reefs (mode $=3.5 \mathrm{~cm}$ TL; Fisher's exact test between fish $\leq 3.5 \mathrm{~cm}$ vs $\geq 4.0 \mathrm{~cm}$ TL; $\mathrm{p}=0.001, \mathrm{n}=25$ ).

\section{Observations of transient predators}

Remote video observations revealed that 3 species of transient predators visited the experimental reefs large schools of 10 to $20 \mathrm{~cm}$ TL Caranx ruber (bar jack), small groups of $15 \mathrm{~cm}$ TL C. bartholomaei (yellow jack), and solitary 50 to $100 \mathrm{~cm}$ TL Sphyraena barracuda (great barracuda). C. ruber were by far the most prevalent, totaling 648 predator minutes (10.8 predator hours) during a total of $30.8 \mathrm{~h}$ of observation. $\mathrm{C}$. bartholomaei and $S$. barracuda were relatively rare, accounting for only 81 and 87 predator minutes over the reefs, respectively.

There was no significant difference in the amount of time Caranx ruber and Sphyraena barracuda spent over experimental reefs between the 2 predation treatments $(Z=1.07$. $\mathrm{p}=0.29$ for bar jack; $Z=0.54, \mathrm{p}=0.59$ for bar racuda; $n=3$ pairs each, Wilcoxon SignedRanks Tests). C. bartholomaei were observed only over a single predator-absent reef on 3 different dates.

The occurrence of transient predators over the experimental reefs exhibited pronounced diel patterns. All Caranx bartholomaei were observed only during the fourth daily sampling period (15:30 to 15:54 h). Sphyraena barracuda were absent at dawn and dusk and observed mostly during the same period as C. bartholomaei. C. ruber were observed during all 5 daily periods, but rarely at dawn and dusk. The number of predator minutes $C$. ruber spent over the reefs during the 3 midday periods (beginning at $08: 30,11: 00$, and $15: 30 \mathrm{~h}$ ) was not significantly different (1-way ANOVA; $F=$ $0.02, \mathrm{p}=0.98, \mathrm{df}=2$ )

Most importantly, we never observed any transient piscivore make what could be remotely considered a predatory strike at recruits on our experimental reefs. Instead, these fish simply passed over the reefs about $1 \mathrm{~m}$ above the bottom. The video samples also never detected resident predators making predatory strikes, which we expected because of the relatively secretive behavior of these piscivores.

\section{DISCUSSION}

\section{Predator effects on survivorship}

Our experiments on translocated coral patch reefs suggest that resident piscivores (moray eels, large squirrelfishes, groupers, and snappers) substantially lowered the survivorship of new reef-fish recruits and that this effect differed markedly among the 3 species of recruits examined. The survivorship of both Chromis cyanea and Halichoeres pictus was significantly greater on reefs where resident predators had been removed than on unmanipulated controls. There was no significant effect of resident predators on Thalassoma bifasciatum.

Previous studies have examined survival of new recruits of both Chromis cyanea and Thalassoma bifas- 
ciatum on reefs where predators were unmanipulated. In the Virgin Islands, survivorship of C. cyanea 1 to 2 mo after recruitment ranged from 0 to $100 \%$ on artificial reefs (Hixon \& Beets 1993) and 46 to $84 \%$ on natural reefs (Booth \& Beretta 1994), compared to an average of $9.4 \%$ on our unmanipulated reefs. This wide range of survivorship appears to be a function of the availability of shelter from predators (de Boer 1978, Hixon \& Beets 1993). Regarding $T$ bifasciatum, survivorship the first month after recruitment was approximately $41 \%$ off the Caribbean coast of Panama (Victor 1986, extracted from his Fig. 9) and ranged from about 43 to $82 \%$ off Barbados (Hunt von Herbing \& Hunte 1991, extracted from their Figs. 8 \& 9). These estimates are near the range observed in this study on unmanipulated reefs, where survival after 1 mo averaged $37.8 \%$.

Effects of our predator manipulations on the survivorship of new recruits did not appear to be an artifact of having handled and transplanted fish between reefs. The separate transplant-control experiment showed that, at least for Halichoeres pictus (this study) and Chromis cyanea (Hixon \& Carr unpubl.), our manipulative procedure of transplanting new recruits from one reef to another, per se, did not affect survivorship. Similarly, Wellington (1992) found that persistence of cohorts of 2 damselfish species transplanted to reefs within their natural range of settlement depths was high (only 12 and $16 \%$ losses over $100 \mathrm{~d}$ for each species). Such results are encouraging, considering the common practice of transplanting recruits in experimental studies of reef fishes (e.g. Doherty 1983, Jones 1987, 1990, Forrester 1990).

\section{Predator effects on size distributions}

Only Chromis cyanea showed a significant change in size distribution during the predator-removal experiment. After a month, survivors were slightly but significantly larger on the predator-present than on the predator-absent reefs. This pattern suggested that resident predators differentially consumed smaller recruits and/or that, once predators reduced densities, the survivors grew faster. Although this size shift was slight, we are convinced that it is real because $C$. cyanea was the species whose survivorship responded most strongly to the predator removals and was the only species showing a size shift.

The only other experimental field study of piscivore effects on prey-size distribution in marine fishes found a different pattern than was detected in our study. Wright et al. (1993) found that Paralichthys lethostigma (southern flounder) differentially consumed intermediate-sized Leiostomus xanthurus (spot) and the largest size classes of the killifishes Cyprinodon variegatus and Fundulus heteroclitus in a North Carolina (USA) estuary. Such differences between systems indicate that the effects of predators on the size distributions of their prey depend upon various factors, including the relative sizes of predator and prey, the behavioral capabilities of the prey at different sizes, and the relative availability and quality of prey refuge (Werner \& Gilliam 1984).

\section{Role of transient predators}

Our preliminary video observations did not detect attacks by transient predators (mostly jacks) on new recruits. However, we suspect that these transient piscivores may 'trap-line' reefs, perhaps attacking any targets of opportunity as they pass each patch. Such mid-sized schooling piscivores appear to spend little time over each reef and soon leave if susceptible prey are not immediately apparent. We have no evidence that either larger or smaller transient predators affect new recruits in this system. We never observed larger transients, such as sharks, barracuda, and large jacks, attack new recruits, and smaller transients, such as lizardfish (see Sweatman 1984), are rare at our site. However, more extensive sampling of the activities of transient predators will be necessary to substantiate these conclusions. For example, the high isolation of our transplanted reefs may have decreased the frequency of visitation by transient predators relative to unmoved reefs, so that our experimental data may have underestimated the normal impact of such predators on early post-settlement mortality. Also, the impact of any (as yet unidentified) nocturnal transient predators is presently unknown.

\section{Species-specific impacts of predation}

Our results generate 3 questions relative to the species-specific impacts of predation. First, why was there no significant effect of resident predators on new recruits of Thalassoma bifasciatum? We suggest 2 possibilities. Although all 3 species we studied are planktivorous at least as new recruits, $T$. bifasciatum seemed to stay closer to shelter provided by the reef than both Chromis cyanea and Halichoeres pictus, and so may have been less vulnerable to predation. Additionally, juvenile $T$ bifasciatum are well-documented cleaner fish and their major hosts are predatory fishes (Randall 1967), which may offer them some immunity to predation.

Second, why did resident predators affect survivorship of Chromis cyanea mostly early in the experiment 
and Halichoeres pictus mostly toward the end? Similar differences in relative patterns of survivorship among species have also been observed on the Great Barrier Reef (Sale \& Ferrell 1988). One possible explanation is that different patterns of survivorship arise from differential conspicuousness and behavioral susceptibility of coexisting prey species. On one hand, C. cyanea in our system are bright blue and form loose feeding aggregations just above the incurrent edge of the reef. On the other hand, recruits of $H$. pictus form denser schools in which individuals constantly shift positions. Indeed, $C$. cyanea are very easy for divers to census relative to $H$. pictus. It seems possible that the resident predators may have first concentrated their efforts on the relatively vulnerable C. cyanea, then shifted to the $H$. pictus after the wrasse reached a more conspicuous size. Similar differences in the apparent effects of predators between prey species have been noted for new recruits of Greal Barrier Reef fishes (Doherty \& Sale 1985, Eckert 1987).

Another possibility is that a particularly voracious school of transient predators passed the predatorpresent reefs undetected and caused the abrupt decline in Chromis cyanea between Days 2 and 3 of the experiment (Fig. 3A) and between Days 21 and 27 in Halichoeres pictus (Fig. 3B). This explanation seems implausible because it would have required the transient predators to concentrate their activity disproportionately on the predator-present reefs, which seems unlikely because these reefs were interspersed with the predator-absent reefs. Moreover, our limited video samples did not detect active feeding by transient piscivores over the reefs, although nearly continuous monitoring would be required to test this explanation rigorously.

A final possibility is that marked declines in 'survivorship' may have actually been predator-induced emigration events. Although isolation of the reefs presumably inhibited emigration, we were forced to discard 1 of the control reefs for Chromis cyanea in the predator-removal experiment and 1 of the transplant reefs in the transplant-control experiment because the entire cohort disappeared immediately (within 1 d) after being transplanted. We suspect that rapid disappearances on these 2 reefs were indeed emigration events because, first, they occurred shortly after the transplants and, second, the decline was precipitous compared to the more gradual declines on the other reefs over the duration of the experiments. We considered such 'all-or-none' disappearances within $1 \mathrm{~d}$ of transplanting new recruits an unusual artifact, which is one reason we started our experiments ('Day 0') a full day after the transplants. The only other field studies of survivorship of $C$. cyanea recruits were conducted in the Virgin Islands. Both studies showed apparently gradual declines, one over 6 mo (bimonthly censuses, Hixon \& Beets 1993), and the other over $30 \mathrm{~d}(10 \mathrm{~d}$ between censuses, Booth \& Beretta 1994). Overall, we suspect that emigration was not a major factor during our experiments, as previously demonstrated for another damselfish on the Great Barrier Reef (Forrester 1990)

The third and perhaps the most important question raised by our study is why was survivorship on the predator-absent reefs so low, averaging only about 40 to $80 \%$ after a month? There are 2 possible explanations, which are not mutually exclusive. First, intraspecific competition or some other factor may have caused fish to emigrate at a steady rate, which we believe is unlikely due to the extreme isolation of our experimental reefs and the fact that emigration appeared to be an all-or-none response. Second, there may have been other sources of predation on the reefs besides the resident piscivores we removed. When transplanting fish, we noticed that large Halichoeres bivittatus (slippery dick wrasse), which are only weakly associated with reefs, sometimes attacked the new recruits just after release. This seemed to be a temporary phenomenon, which is another reason we started the experiments a full day after the final transplants. However, despite our limited video evidence to the contrary, it is also possible that transient predators accounted for the disappearance of recruits from reefs where resident predators had been removed. Therefore, we are now investigating more closely the roles of different sources of predation in affecting early post-settlement survivorship

\section{Population vs community-level effects of predation}

Because resident carnivorous fishes capable of consuming small recruits are ubiquitous on coral reefs (review by Hixon 1991) and exhibit high spatial and temporal variability in local abundance (Hixon \& Beets 1993. Carr \& Hixon unpubl.), our results suggest that early post-settlement predation can be a major process affecting local population sizes of Bahamian reef fishes. This conclusion reflects similar findings in the Virgin Islands (Shulman 1985, Hixon \& Beets 1993) and the Great Barrier Reef (Caley 1993). High postsettlement mortality appears to actually prevent the establishment of an adult population of Halichoeres pictus at our site. Despite moderate to high densities of new recruits each year from at least 1990 to 1994, we have never encountered an adult of this species in our censuses (Hixon \& Carr unpubl.). Note, however, that our experiments were not designed to answer the question of whether predation. regulates local population densities of reef fishes. Population regulation can 
only be demonstrated by examining a range of initial cohort densities (Sinclair 1989).

Our results do suggest that piscivores affect the postsettlement survivorship of some species more than others. If this is a common pattern, then predation may have an important role in structuring local reef-fish assemblages. Indeed, predation has been demonstrated to be a major process structuring populations and communities in other marine and freshwater systems (reviews by Connell 1975, Zaret 1980, Sih et al. 1985). It would be unusual if predation did not also contribute substantially to the structure and dynamics of reef-fish populations and the assemblages they comprise.

Acknowledgements. We are grateful to J. Beets, R. Gomez, W. Head, S. Thompson, and especially A. Kaltenberg and S. Swearer for heroic help in the field. We appreciate the generous hospitality of S. Hall, W. Head, Kerlene, G. Wenz, and R. Wicklund at Lee Stocking Island. We thank A. T Kaltenberg, B. A. Menge, G. P. Jones, and 3 anonymous reviewers for providing constructive criticism of the manuscript. This research was supported by the National Undersea Research Program at the Caribbean Marine Research Center (courtesy of $R$. Wicklund) and by a grant from the National Science Foundation (OCE-92-17163).

\section{LITERATURE CITED}

Booth DJ, Beretta GA (1994) Seasonal recruitment, habitat associations, and survival of pomacentrid reef fish in the US Virgin Islands. Coral Reefs 13:81-89

Caley MJ (1993) Predation, recruitment and the dynamics of communities of coral-reef fishes. Mar Biol 117:33-43

Connell JH (1975) Some mechanisms producing structure in natural communities: a model and evidence from field experiments. In: Cody ML, Diamond JA (eds) Ecology and evolution of communities. Belknap-Harvard Univ Press, Cambridge, p 460-490

Connell JH (1985) The consequences of variation in initial settlement vs post-settlement mortality in rocky intertidal communities. J exp mar Biol Ecol 93:11-45

de Boer BA (1978) Factors influencing the distribution of the damselfish Chromis cyanea (Poey), Pomacentridae on a reef at Curacao, Netherlands Antilles. Bull mar Sci 28 : $550-565$

Doherty PJ (1983) Tropical territorial damselfishes: is density limited by aggression or recruitment? Ecology 64:176-190

Doherty PJ (1991) Spatial and temporal patterns in recruitment. In: Sale PF (ed) The ecology of fishes on coral reefs. Academic Press, San Diego, p 261-293

Doherty PJ, Sale PF (1985) Predation on juvenile coral reef fishes: an exclusion experiment. Coral Reefs 4:225-234

Doherty PJ, Williams DM (1988) The replenishment of coral reef fish populations. Oceanogr mar Biol A Rev 26 $487-551$

Eckert GJ (1987) Estimates of adult and juvenile mortality for labrid fishes at One Tree Reef, Great Barrier Reef Mar Biol 95:167-171

Forrester GE (1990) Factors influencing the juvenile demography of a coral reef fish population. Ecology 71 : $1666-1681$
Gaines S, Roughgarden J (1985) Larval settlement rate: a leading determinant of structure in an ecological community of the marine intertidal zone. Proc natl Acad Sci USA 82:3707-3711

Hixon MA (1991) Predation as a process structuring coral reef fish communities. In: Sale PF (ed) The ecology of fishes on coral reefs. Academic Press, San Diego, p 475-508

Hixon MA, Beets JP (1989) Shelter characteristics and Carıbean fish assemblages: experiments with artificial reefs. Bull mar Sci 44:666-680

Hixon MA, Beets JP (1993) Predation, prey refuges, and the structure of coral-reef fish assemblages. Ecol Monogr 63:77-101

Hunt von Herbing I, Hunte W (1991) Spawning and recruitment of the bluehead wrasse Thalassoma bifasciatum in Barbados, West Indies. Mar Ecol Prog Ser 72:49-58

Jones GP (1987) Competitive interactions among adults and juveniles in a coral reef fish. Ecology 68:1534-1547

Jones GP (1990) The importance of recruitment to the dynamics of a coral reef fish population. Ecology 71:1691-1698

Jones GP (1991) Postrecruitment processes in the ecology of coral reef fish populations: a multifactorial perspective. In Sale PF (ed) The ecology of fishes on coral reefs. Academic Press, San Diego, p 294-328

Leis JM (1991) The pelagic stage of reef fishes: the larval biology of coral reef fishes. In: Sale PF (ed) The ecology of fishes on coral reefs. Academic Press, San Diego, p 183-230

Menge BA (1991) Relative importance of recruitment and other causes of variation in rocky intertidal community structure. J exp mar Biol Ecol 146:69-100

Raimondi PT (1990) Patterns, mechanisms, and consequences of variability in settlement and recruitment of an intertidal barnacle. Ecol Monogr 60:283-309

Randall JE (1967) Food habits of reef fishes of the West Indies Stud Trop Oceanogr 5:665-847

Reed DC (1990) The effects of variable settlement and early competition on patterns of kelp recruitment. Ecology 71 : $776-787$

Reed DC, Laur DR, Ebeling AW (1988) Variation in algal dispersal and recruitment: the importance of episodic events. Ecol Monogr 58:321-335

Robertson DR (1988) Abundances of surgeonfishes on patchreefs in Caribbean Panama: due to settlement, or postsettlement events? Mar Biol 97:495-501

Sale PF (1991) Reef fish communities: open nonequilibrial systems. In: Sale PF (ed) The ecology of fishes on coral reefs. Academic Press, San Diego, p 564-598

Sale PF, Ferrell DJ (1988) Early survivorship of juvenile coral reef fishes. Coral Reefs 7:117-124

Santelices B (1990) Patterns of reproduction, dispersal and recruitment in seaweeds. Oceanogr mar Biol A Rev 28: $177-276$

SAS Institute Inc (1988) SAS/STAT user's guide, release 6.03 edn. SAS Institute Inc, Cary, NC

Shulman MJ (1985) Recruitment of coral reef fishes: effects of distribution of predators and shelter. Ecology 66: $1056-1066$

Shulman MJ, Ogden JC (1987) What controls tropical reef fish populations: recruitment or benthic mortality? An example in the Caribbean reef fish Haemulon flavolineatum. Mar Ecol Prog Ser 39:233-242

Sih A, Crowley P, McPeek M, Petranka J, Strohmejer K (1985) Predation, competition, and prey communities: a review of field experiments. A Rev Ecol Syst 16:269-311

Sinclair ARE (1989) Population regulation in animals. In: Cherrett JM (ed) Ecological concepts: the contribution of ecology to an understanding of the natural world. Black- 
well Scientific Publications, Oxford, p 197-241

Sweatman HPA (1984) A field study of the predatory behavlour and feeding rate of a piscivorous coral reef fish, the lizardfish Synodus englemani. Copeia 84:187-193

Sweatman HPA (1993) Tropical snapper (Lutjanidae) that is piscivorous at settlement. Copeia 1993:1137-1139

Underwood AJ, Denley EJ, Moran MJ (1983) Experimental analyses of the structure and dynamics of mid-shore rocky intertidal communities in New South Wales. Oecologia $56: 202-219$

Underwood AJ, Fairweather PG (1989) Supply-side ecology and benthic marine assemblages. Trends Ecol Evol 4: $16-19$

Victor BC (1986) Larval settlement and juvenile mortality in

This article was submitted to the editor a recruitment-limited coral reef fish population. Ecol Monogr 56:145-160

Wellington GM (1992) Habitat selection and juvenile persistence control the distribution of two closely related Caribbean damselfishes. Oecologia 90:500-508

Werner EE, Gilliam JF (1984) The ontogenetic niche and species interactions in size-structured populations. A Rev Ecol Syst 15:393-425

Wright RA, Crowder LB, Martin TH (1993) The effects of predation on the survival and size-distribution of estuarine fishes: an experimental approach. Environ Biol Fishes $36: 291-300$

Zaret TM (1980) Predation and freshwater communities. Yale University Press, New Haven, CT

Manuscript first received: July 4, 1994

Revised version accepted: March 8, 1995 